\title{
Enhancing English Speaking Skill by Using AFORN, an M-Learning Medium for Nursing Students
}

\author{
Desi Rochmawati ${ }^{1 *}$ and Ika Fathin Resti Martanti ${ }^{2}$
}

\author{
${ }^{1}$ Poltekkes Kemenkes Yogyakarta, Indonesia (Health Polytechnic of Ministry of Health in Yogyakarta) \\ ${ }^{2}$ Sekolah Tinggi Teknologi Kedirgantaraan, Yogyakarta, Indonesia (College of Aerospace Technology, Yogyakarta) \\ *Corresponding author. Email: brilliantdesy@gmail.com
}

\begin{abstract}
Speaking skill is an English language competence that is very important for effective communication either in educational or professional environment. This skill is also required by students of Nursing Study Program to support their academic and professional development. However, students still have limited exposure to English materials related to their field of science. Active English for Nursing (AFORN) application, therefore, it was elaborated to support the students' needs. AFORN is an Android-based application for learning English speaking skills as complementary learning media that are accessible at anytime and anywhere. The objective of this study was to observe how AFORN helped students enhance their speaking skills. This was an Action Research project. The subjects of this study were the second-semester students of Nursing Study Program. The data were collected by doing observation, interview, and tests. There were four stages in this study, namely planning, action, observation, and reflection. The focus of the Action stages was implementing AFORN as an m-learning medium to help students learn English based on their own pace. The result of this study shows that there was an improvement of students' speaking skills in terms of vocabulary, grammar, language expressions, and pronunciations. Besides the students became more motivated to learn English after using the alternative learning medium i.e. AFORN which could be flexibly accessed through their Android-based gadgets.
\end{abstract}

\section{Keywords: AFORN, enhance, speaking, m-learning, active learning, complementary learning media}

\section{INTRODUCTION}

The Asian Economic Community (AEC), which is currently underway, requires Indonesian workers to have international language skills, namely English. English is used to interact with foreigners in the work fields, in finding jobs, in continuing studies, and many others. Mastery of English includes four language competencies, namely listening, speaking, reading, and writing. These language skills are interrelated with each other in terms of comprehensive mastery of the English language.

Four language skills support each other for the achievement of a comprehensive mastery of the language which is called the achievement of learning English. Furthermore, English is regarded as a foreign language in Indonesia, and it is primarily used in English lessons rather than in everyday communication. For English learners, the ability to speak English is a precedence since its success is usually measured by their oral competence [1].

Nowadays teaching speaking is required to be more interesting and innovative by using the latest teaching media. In recent years, mobile phones have switched functions into Android-based smartphones. Android applications are also developing along with the development of increasingly widespread smartphones using Android as an operating system. Prayogi (2014) in his article stated that the use of smartphones in the world increased 4.55 billion in 2014. That number was estimated to reach a total of 5.645 billion by 2020 [2].

Android applications develop in various products. One of the Android applications for learning English is AFORN (Active English for Nursing) - an Androidbased teaching medium used for learning speaking. AFORN was researched and developed by Rochmawati (2015) [3]. AFORN is a learning model with the principle of mobile learning (m-learning) to help students learn vocabulary and speaking (pronunciation). By using AFORN, students can learn English anywhere and anytime by accessing AFORN on their smartphones.

Lack of opportunity to practice speaking in English is also an obstacle to be able to speak fluently and correctly. English is mostly used in English classes. The second problem is related to the content of the syllabus which gives a small portion of speaking skills. This also has an impact on the lack of opportunities for students to practice speaking orally. The third problem that is also an obstacle in mastering spoken English is the busy schedule of students in practical activities outside of English 
courses. Another problem is that because English in Indonesia was still used as a foreign language hence the exposure to English received by students is also limited. Many students who come from the suburbs are less interested in English language skills, so that students' English skills, in general, are still low and lack motivation. Based on those findings, this research try to answer the research question which focus on the way of AFORN, an m-learning medium to improve the speaking skills for students of Diploma III of Nursing Study Program.

This study aims to improve English speaking skills through the use of learning media, specifically an English learning application called AFORN (Active English for
Nursing), which can be installed on any Android-based smartphones.

Several components of teaching, particularly teaching speaking, are essential for English teachers to know and comprehend. Teachers, according to Goh \& Burns (2012), must understand the requirements for speaking skills, and the way of different aspects of speaking competences relate to one another, in order to arrange and deliver lessons which are capable to enhance students' speaking skills in an appropriate manner, as well as approach teaching materials in an informed and critical way [4]. The table below demonstrates a compilation of many language teachers' perspectives that provide certain indicators for people learning speaking skill.

Table 2.4. Second Language Speakers' Competences adapted from Burns (2017) [5].

Competent second language speakers are those who meet these requirements like able to;

a) pronounce the English vocabularies correctly.

b) speak English in a standard way.

c) speak fluently with minor grammatical errors.

d) speak in different accent than native speakers.

e) be confidence in public speaking situations.

f) understand the situation to say the right things and express them effectively.

g) communicate well with native speakers.

h) be understood by others.

i) communicate effectively and clearly in various situations

j). know how to code-switch from the first to the second language, depends on the circumstances.

k) speak flawlessly on various topics.

Active learning is learning strategies which consist of various kinds of elements of society's activities that engage students in what they do and what they think about (Bonwell \& Eison 1991). Instructional active learning strategies can be developed and applied to involve students in thinking critically and creatively, talking in any kinds of groups, expressing ideas through writing, explore personal attitudes and values, giving and receiving feedback, and reflections [6].
AFORN is an Android-based application developed by the researcher as a complementary learning medium for students of Nursing Study Program at the Health Polytechnic of Ministry of Health in Yogyakarta (Poltekkes Kemenkes Yogyakarta). In developing the application, the researcher considered the English course syllabus for the Nursing Study Program, the theories of speaking skills, and the m-learning principles. The table 2.5 below shows the concepts of the development of the application.

Table 2.5 The Concepts of Materials in AFORN

\begin{tabular}{|c|c|c|c|}
\hline $\begin{array}{c}\text { Learning } \\
\text { Objectives }\end{array}$ & $\begin{array}{c}\text { Core Speaking } \\
\text { Skills }\end{array}$ & Features in AFORN & Objectives \\
\hline $\begin{array}{l}\text { - Understanding } \\
\text { English } \\
\text { conversation }\end{array}$ & Pronunciation & $\begin{array}{l}\text { Pronunciation practice feature using text to } \\
\text { speech and speech recognizer }\end{array}$ & $\begin{array}{l}\text { Students can practice pronunciation } \\
\text { correctly so that they are able to } \\
\text { pronounce well. }\end{array}$ \\
\hline $\begin{array}{l}\text { - Writing nursing } \\
\text { care reports in } \\
\text { English }\end{array}$ & Speech function & $\begin{array}{l}\text { A feature that focuses on expressions that are } \\
\text { commonly used in conversation. }\end{array}$ & $\begin{array}{l}\text { Students know the right expressions so } \\
\text { that they are able to display good } \\
\text { speaking skills. }\end{array}$ \\
\hline $\begin{array}{l}\text { - Listening to reports } \\
\text { and nursing issues }\end{array}$ & $\begin{array}{l}\text { Managing } \\
\text { Interaction }\end{array}$ & $\begin{array}{l}\text { A feature that provides practice listening to } \\
\text { English conversations. Conversational } \\
\text { practice can be carried out with separate } \\
\text { instructions by the lecturer. }\end{array}$ & $\begin{array}{l}\text { Students are able to appreciate dialogue, } \\
\text { especially the interaction between nurses } \\
\text { and patients. }\end{array}$ \\
\hline $\begin{array}{l}\text { - Doing presentation } \\
\text { in English }\end{array}$ & $\begin{array}{l}\text { Organizing } \\
\text { conversation }\end{array}$ & $\begin{array}{l}\text { - A feature that trains grammar skills } \\
\text { - Features that include vocabulary exercises }\end{array}$ & $\begin{array}{l}\text { Students are able to make complex } \\
\text { conversations with various speaking } \\
\text { genres through grammatical and lexical } \\
\text { options. }\end{array}$ \\
\hline
\end{tabular}


In creating the content in AFORN, the researcher also uses several books as references. English for Professional Nursing 2 and Cambridge English for Nursing (Preintermediate) books. Both books consist of topics which are relevant for teaching and learning English in Nursing program.

The advancement of communication technology increases rapidly. This has the same ways with the development of mobile devices such as smartphones or tablets with their various types, versions, and specifications. Mobile devices have developed the functions for communications and as learning media as well. The revolutions of mobile devices has changed the e-learning to mobile learning (m-learning) which is right now considered as the reincarnation of e-learning [7].

Mobile learning, often known as m-learning, is a sort of e-learning that uses wireless communication devices to deliver educational content and learning support materials. According to Traxler in Cabanban (2013), mobile learning is a personal tool that allows students to connect and interact with gadgets in teaching learning process. Recently, actual implementations of m-learning has developed faster than others (pp. 7) [8]. KukulskaHulme and Traxler (2005) states that another concept of m-learning is learner mobility that promotes students to carry out educational activities in different situations and without having them in certain physical locations. Mobile learning refers to the definition of m-learning, including spontaneity, personalization, informality, context, portability, and flexibility (pp. 1-2) [9].

In designing dan developing AFORN, the researcher employed the Universal Instructional Design (UID) principles. Elias (2011) states that there are eight principles of UID which are highly effective in distance education [10]. Further definitions of the eight principles are listed in Elias (2011); namely 1) fair use (accessible to different abilities and locations), 2) flexible use (accommodate various individual abilities, preferences, connectivity, and the method), 3) simple and intuitive, 4) clear information, 5) error tolerance (minimizes errors in software), 6) minimal technical and physical effort (developed with only light technical and physical effort), 7) learner community and support (by chat or messages), 8) instructional atmosphere (enable lecturers to send messages to interact with students in various ways using social media communications like WhatsApp and Facebook).

Users can find lots of various applications in this digital era. Those applications have several categories such as communications, news, entertainment, education, lifestyle and many others. This shows that mobile technology has influenced many other fields including education. Kukulska-Hulme and Lesley (2008) mentions that the use of mobile devices to support language learning is becoming more common now in society [11].

There are several studies related to the implementation of mobile learning as a learning method. Kim (2008) uses cell phones to introduce vocabulary through short stories to children in remote areas of Latin America. Another research related to students' perceptions and experiences of using mobile learning as a learning medium is the research conducted by Kim, Rueckert, and Kim (2013) [12]. In a study using research and development (R \& D) design by Rochmawati (2015), AFORN was created to meet the need for alternative learning media that are practical and can be accessed anywhere and anytime and in accordance with the principles of m-learning.

The theories that support this study include competencies to be mastered in improving speaking skills, principles of m-learning media development, and pedagogical principles associated with learning concepts using AFORN. The various theories used to support this research can be seen in the following chart.

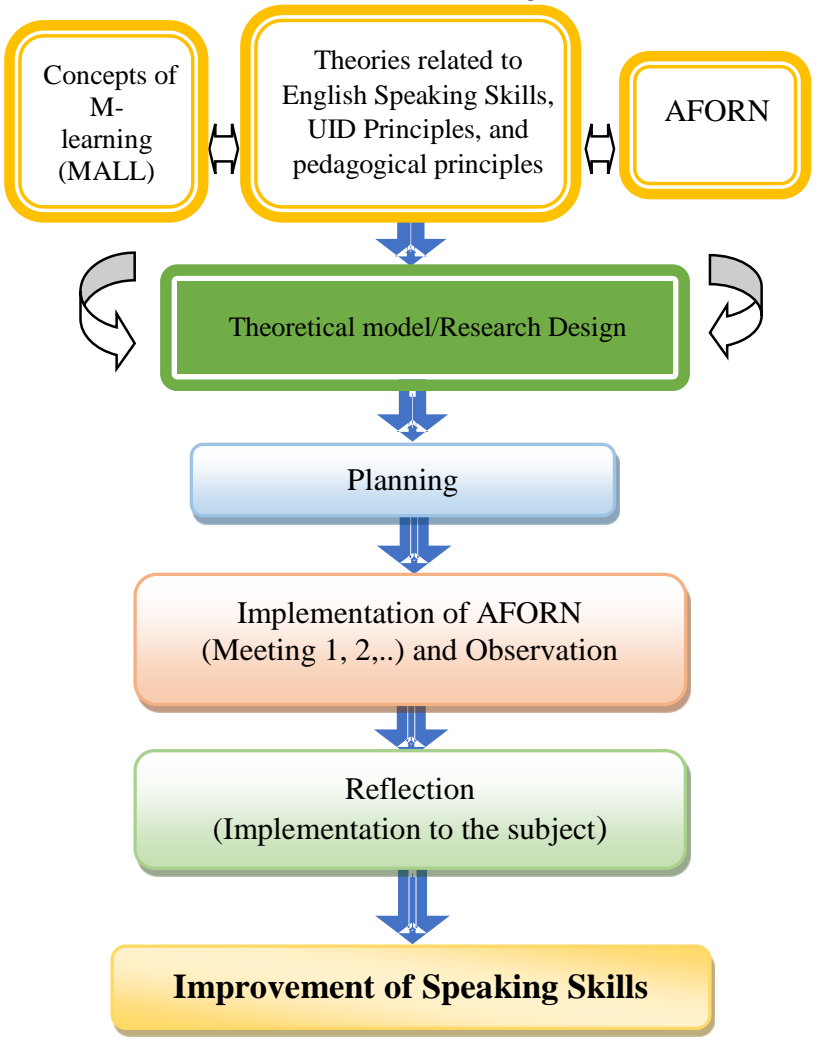

Figure 1.1 Theoretical Framework of the Improvement of Speaking Skills with AFORN

In addition, to develop a learning application that can accommodate the learning materials in line with the students' needs, the site map was developed to help researchers make links between sections in the application. The site map of AFORN can be seen as in the figure below. 


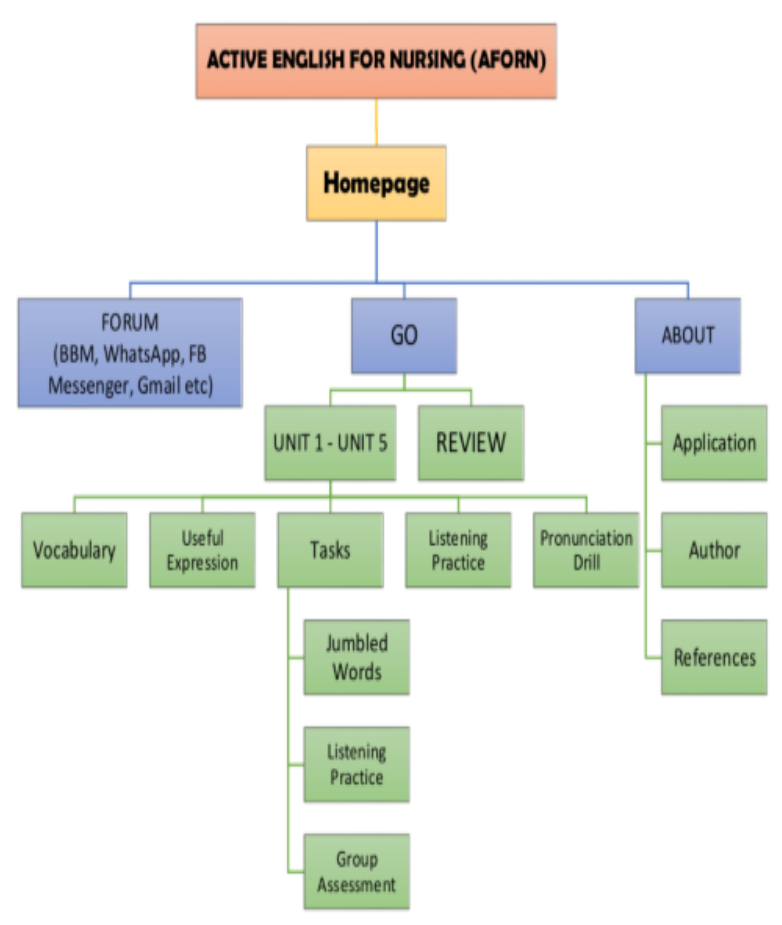

Figure 1.2. Site Map of AFORN

Figure 1.2 is a site map of AFORN containing five discussion units in the application; namely Unit 1 Asking The Dimension of Symptoms, Unit 2 Starting An Intervention, Unit 3 Giving Injection, Unit 4 Applying Infusion, and Unit 5 Taking The Lab Sample. Each unit is equipped with practice questions to display scores after completing the practice questions. In each unit there are 4 types of exercises; Vocabulary, Useful Expression, Tasks and Pronunciation Drill.

\section{METHODOLOGY}

The stages of this research include the stages of planning, action, observation and reflection. Kemmis and McTaggart (1988) in Burns (2010) proposes that action research occurs through a dynamic and complementary research process which consist of four stages; planning, action, observation, and reflection [13]. The cycles of an action research can be illustrated in the following figure.

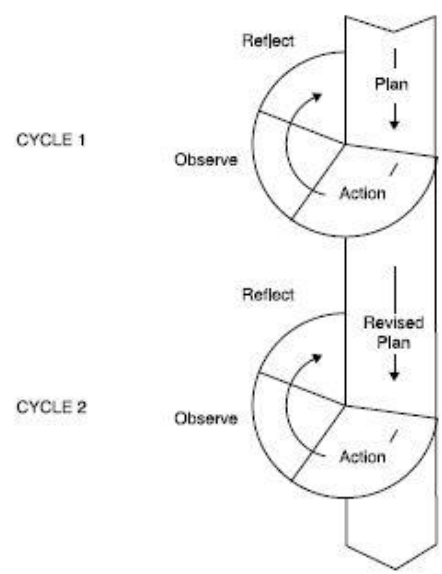

Figure 3.1. Action Research Cycle by Kemmis and McTaggart (1988)

\subsection{Planning (Planning)}

In this stage, researchers made plans for actions that were implemented in the teaching and learning process. Researchers prepared material based on student needs, namely English for nursing. The pre-test and post-test were also designed in this stage. The material already existed in the form of an m-learning model that was installed on an Android-based smartphone, namely AFORN. The material in AFORN was adjusted to the needs of nursing students.

\subsection{Action}

After planning, researchers and English lecturers in the Department of Nursing implemented AFORN as a learning medium in the teaching and learning process of English which emphasized the ability to speak. This stage was carried out inside and outside the classroom. The Action was carried out until there was an improvement in student abilities.

\subsection{Observation}

During the action process, researchers and collaborators observed everything that happened in the teaching and learning process. The learning process could actually be done anywhere and anytime according to the principles of mobile learning.

\subsection{Reflection}

On the previous stages, a reflection on the implementation of AFORN (action stage) was carried out. In this stage, all the successes and problems that arose in each implementation (action) were discussed and solutions were given by researchers and collaborators so that researchers could make improvements for the next cycle.

This study applied an action research design with mix method approach which trying to solve problems existing in the teaching and learning process through the use of an android-based learning model called AFORN. The problem solving was done by applying AFORN which was expected to solve the existing problems and improve the teaching and learning process, especially for speaking skills. The action research was conducted based on planning, implementation (implementation of AFORN), observation, and reflection.

This research was conducted at the Department of Nursing, Health Polytechnic of Ministry of Health in Yogyakarta. The participants in this study were students of the D-III Nursing Study Program at the Yogyakarta Health Polytechnic with a total of 40 students. The sample selection in this study was based on the learning application that had been created for the benefit of previous research, namely AFORN.

The data in this study were qualitative and quantitative data. The qualitative data were taken from field notes, interview transcripts, and questionnaires. The quantitative data were in the form of speaking comprehension which included vocabulary mastery, pronunciation, language expression mastery, and grammar mastery carried out in the form of pre-test and post-test.

Techniques in data collection were carried out in several ways; observation, interview and test. 
Observations were made to find out the situation and conditions in the classroom when the action was carried out. Researchers and collaborators observed the English teaching and learning process. In the observation, the instrument needed was an observation sheet containing several steps in implementing the action.

Since this study applied mix method approach, there were qualitative and quantitative. The qualitative data obtained from the results of interviews and observations. After the data were collected, the data were identified and concluded. In addition to qualitative data, there were quantitative data. The researcher analyzed the quantitative data from the scores obtained from the test (pre-test and post-test) of speaking ability using the SPSS program. After that, the students' speaking skill scores were presented in the mean scores.

\section{RESULT AND DISCUSSION}

Based on observations made in the class, syllabus for English courses, and interviews with collaborators, several problems were found in this stage. Based on the problems found and their causes, the researcher then implemented a model of teaching and learning by using AFORN, an m-learning application that can be accessed using an Android-based smartphone. In AFORN, there are 5 units; Unit 1 Asking The Dimension of Symptoms, Unit 2 Starting An Intervention, Unit 3 Giving Injection, Unit 4 Applying Infusion, and Unit 5 Taking The Lab Sample. Each unit is equipped with practice questions to display scores after completing the practice questions. In each unit there are 4 types of exercises; Vocabulary, Useful Expression, Tasks and Pronunciation Drill. By using AFORN, problems in the teaching and learning process of English can be solved as shown in the following table.

Table 4.1 Problem Solving in Learning English with AFORN

\begin{tabular}{|c|c|c|c|}
\hline No. & Problems & Causes & Solutions \\
\hline 1. & $\begin{array}{l}\text { Students have limited } \\
\text { time to get English } \\
\text { language material }\end{array}$ & $\begin{array}{l}\text { English lessons are only held for } \\
2 \text { semesters during the study } \\
\text { period with a schedule once a } \\
\text { week. }\end{array}$ & $\begin{array}{l}\text { Students can still learn English outside of class } \\
\text { using AFORN which can be accessed anywhere } \\
\text { and anytime (self-learning) }\end{array}$ \\
\hline 2. & $\begin{array}{l}\text { Students get speaking } \\
\text { material with little } \\
\text { frequency }\end{array}$ & $\begin{array}{l}\text { The material taught includes } 4 \\
\text { English skills so that each gets } \\
\text { the same portion }\end{array}$ & $\begin{array}{l}\text { Students practice speaking by accessing } \\
\text { AFORN, especially in the Useful Expression and } \\
\text { Pronunciation Drill sections }\end{array}$ \\
\hline 3. & $\begin{array}{l}\text { Some students lack } \\
\text { confidence when } \\
\text { speaking in English }\end{array}$ & $\begin{array}{llr}\text {-Students } & \text { do not } & \text { practice } \\
\text { speaking } & & \\
\text {-Students } & \text { have } & \text { limited } \\
\text { vocabulary } & & \end{array}$ & $\begin{array}{l}\text { Students practice speaking by accessing } \\
\text { AFORN, especially in the Vocabulary, Useful } \\
\text { Expression, and Pronunciation Drill sections }\end{array}$ \\
\hline 4. & $\begin{array}{l}\text { Students interact } \\
\text { using English only in } \\
\text { English class }\end{array}$ & $\begin{array}{l}\text {-Not many students or lecturers } \\
\text { have good English speaking } \\
\text { skills. } \\
\text {-The limitation of learning media } \\
\text { that focus on speaking skill }\end{array}$ & $\begin{array}{l}\text { - Introduction to English lessons using English. } \\
\text { - Students make video conversations in English } \\
\text { according to the exercises in AFORN. } \\
\text { - Students carry out discussion activities with } \\
\text { friends by using one of the features in AFORN, } \\
\text { namely FORUM }\end{array}$ \\
\hline 5. & $\begin{array}{l}\text { Some students are } \\
\text { less interested in } \\
\text { English language } \\
\text { skills }\end{array}$ & $\begin{array}{l}\text {-Students think English is a } \\
\text { difficult subject. } \\
\text {-Students are bored with the } \\
\text { methods/teaching materials used. }\end{array}$ & $\begin{array}{l}\text { Students can carry out self-learning under the } \\
\text { guidance of a lecturer by accessing AFORN as } \\
\text { an English m-learning media. }\end{array}$ \\
\hline 6. & $\begin{array}{l}\text { Some lecturers only } \\
\text { use books as teaching } \\
\text { materials }\end{array}$ & $\begin{array}{l}\text { Limitations of teaching materials } \\
\text { used }\end{array}$ & $\begin{array}{l}\text { Students carry out the English teaching and } \\
\text { learning activities using flexible teaching } \\
\text { materials, namely AFORN. }\end{array}$ \\
\hline 7. & $\begin{array}{l}\text { The methods used to } \\
\text { learn speaking are } \\
\text { less diverse }\end{array}$ & $\begin{array}{l}\text { Some lecturers have limited } \\
\text { knowledge in developing } \\
\text { teaching materials and materials }\end{array}$ & $\begin{array}{l}\text { - Implementing the English teaching and } \\
\text { learning process using flexible teaching } \\
\text { materials, namely AFORN. } \\
\text { - Give group assignments to make video } \\
\text { conversations in English according to AFORN. }\end{array}$ \\
\hline 8 & $\begin{array}{l}\text { Pronunciation of } \\
\text { vocabulary in English } \\
\text { still needs } \\
\text { improvement }\end{array}$ & Lack of pronunciation practice & Students practice self-learning using AFORN \\
\hline
\end{tabular}

After identifying the most important problems and their causes, the researchers tried to carry out activities (actions) that could solve the problems. After having discussion with several English lecturers, the researchers then implemented an m-learning application (AFORN) to improve students' speaking skills. AFORN is a 
multimedia software that can be accessed by using smartphones. Multimedia software that use text, graphics, sound, and video can increase not only the skills but also the motivation for learners [14].

\subsection{Cycle I}

The implementation of the first cycle was carried out in two meetings. This was done due to the limited time of the researchers and also the participating students.

\subsubsection{Planning}

The researchers identified the problem that was found in teaching learning process. Preparation for the syllabus and lesson plan were also done in this stage. Then, the researchers design the pretest and posttest. The researcher and the participating students determined an English learning schedule outside the regular schedule.

Table 4.2 Timeline in Cycle 1

\begin{tabular}{|c|c|c|}
\hline No. & Activity & Material \\
\hline 1. & Pretest & Pronunciation \\
\hline 2. & $\begin{array}{l}\text { Meeting } 1 \\
\& 2\end{array}$ & $\begin{array}{l}\text { Unit } 1 \text { Asking The Dimension of } \\
\text { Symptom }\end{array}$ \\
\hline 3. & $\begin{array}{l}\text { Meeting } 3 \\
\& 4\end{array}$ & Unit 2 Starting An Intervention \\
\hline 4. & Posttest & $\begin{array}{l}\text { Pronunciation, } \\
\text { Interview }\end{array}$ \\
\hline
\end{tabular}

\subsubsection{Action and Observation}

The pretest participants were 40 students of the D III Nursing Study Program in the second semester. The pretest activity was focused on speaking skills, especially pronunciation skills. The pretest question consists of two parts. The first part was pronunciation practices, the students must pronounce the vocabulary correctly and the second part the students must pronounce the sentences correctly. Pretest was conducted to determine students' speaking ability before using AFORN as an English learning model (m-learning model). The results of the pretest showed that the average student score was 46.25.

The action was carried out in 2 actions (4 meetings) which took place in the classroom. Meanwhile, outside of classroom activities, students are asked to learn English using AFORN as the supplement to face to face portion. They access AFORN whenever they want and wherever they want to be. Action focuses on implementing AFORN to improve students'speaking skills. The data during the first cycle was obtained through class observations and interviews. The full explanation is as follows.

\subsubsection{Action 1 and Observation}

In Action 1, students were introduced to AFORN, an m-learning media for learning English that can be accessed anywhere and anytime. Apart from being easy to access, AFORN also supports the implementation of self-learning. The material implemented is the material contained in Unit 1 Asking the Dimension of Symptom. Within Unit 1 there are several segments, namely; Vocabulary, Useful Expression, Task (Jumbled Words,
Listening Practice, Group Assessment), and Pronunciation Drill. Action 1 consists of 2 sessions; session 1 is the introduction of AFORN which is carried out by researchers in the classroom, while in session 2 students carry out self-learning by accessing AFORN which does not have to be done in class.

\subsubsection{Action 2 and Observation}

Action 2 is a continuation of Action 1 . The researcher provides an introduction to material related to the contents of Unit 2 Starting An Intervention which consists of several segments; Vocabulary, Useful Expression, Task (Jumbled Words, Listening Practice, Group Assessment), and Pronunciation Drill. After getting an explanation from the researcher and practicing briefly, students must do self-learning as was done in Action 1.

The posttest was conducted to determine the students' ability after learning English using AFORN. The posttest consists of 3 parts. In the first part, students must pronounce vocabulary correctly, in the second part students must pronounce sentences correctly, and in the third part students explain nursing action procedures such as Taking Blood Samples and explain the symptoms that arise in certain diseases such as Dengue Fever. The results of the posttest showed a fairly good increase, namely the average student was 84.97.

Based on the result of observation, AFORN as the complementary learning tool was really helpful for students to learn that they can access it as their own schedule and timeline. AFORN gives the students more time to look up other resources. It also promotes autonomy in learning process. Generally AFORN gives flexibility in learning with the students' phase.

\subsubsection{Reflection}

After carrying out cycle 1, the researcher and the elaborator collected data and evaluated it to get a reflection. Reflection was carried out to find out whether Action1 and Action 2 succeeded in improving English speaking skills or not. Reflection is done by analyzing the data from the pretest and posttest results and distributing questionnaires to students. As Creswell (2012) adapted from Mills (2011) that in evaluating action research studies, researchers must collect both quantitative and qualitative data [15].

The data from the pretest and posttest results show that the average pretest score is 46.25 and the posttest average score is 84.97. These data indicate an increase in the average value of 38.75. Data obtained from questionnaires distributed to students indicated that AFORN was considered capable of improving English speaking skills. AFORN is very useful for learning English because it is an innovative, interesting media, and can be accessed anywhere and anytime so that it supports the implementation of self-learning. AFORN also features feedback that appears indicating the correct or incorrect completion of the exercises. AFORN is beneficial to support m-learning experiences. M-learning has improved the learning activities providing high level interaction between separated teachers and learners [16]. 
The results of statistical data processing showed a significant increase in the value between the values (Mean) in the pretest and posttest. The mean obtained from the pretest is only 46.25 , while the mean obtained from the posttest is 84.97 .

Table 4.3 Data of Speaking Ability Test (Speaking)

\begin{tabular}{|c|c|c|}
\hline Test & Frequency & Mean \\
\hline Pre-Test & 40 & 46.25 \\
\hline Post-Test & 40 & 84.97 \\
\hline
\end{tabular}

The table above shows that the Mean obtained from the posttest is higher than the Mean obtained from the pretest. This clearly shows an increase in the ability to speak English.
Monitoring should be emphasized in using AFORN as a complementary learning tool that it will be wellapplied in blended learning or flipped learning models.

Based on the results of observations that have been made to second semester students of the DIII Nursing study program at Poltekkes Kemenkes Yogyakarta, various problems were found in teaching learning process, especially those related to the process of mastering one of the language competencies, namely speaking. To overcome the problems related to students speaking competences, AFORN was implemented as a means of supplementary or complementary learning tool for classroom teaching learning process. Various problems in the English learning process related to speaking competence can be formulated in table 4.4.

Table 4.4 Summary of Progress in the Action Research Cycle

\begin{tabular}{|c|c|c|}
\hline No. & Previous Conditions & Condition after the Implementation of AFORN \\
\hline 1 & $\begin{array}{l}\text { Students have limited time to get } \\
\text { English materials }\end{array}$ & $\begin{array}{l}\text { With AFORN, students have more time to study English } \\
\text { material }\end{array}$ \\
\hline 2 & $\begin{array}{l}\text { Students get speaking material with less } \\
\text { frequency }\end{array}$ & $\begin{array}{l}\text { With AFORN, students get speaking material with more } \\
\text { frequency }\end{array}$ \\
\hline 3 & $\begin{array}{l}\text { Some students lack confidence when } \\
\text { speaking in English }\end{array}$ & $\begin{array}{l}\text { With AFORN, students become more confident when } \\
\text { speaking in English }\end{array}$ \\
\hline 4 & $\begin{array}{l}\text { Students interact using English only in } \\
\text { English class }\end{array}$ & $\begin{array}{l}\text { With AFORN, students can interact using English both inside } \\
\text { and outside the classroom }\end{array}$ \\
\hline 5 & $\begin{array}{l}\text { Some lecturers only use books as } \\
\text { teaching materials }\end{array}$ & $\begin{array}{l}\text { With AFORN, lecturers have a variety of media in teaching } \\
\text { English }\end{array}$ \\
\hline 6 & $\begin{array}{l}\text { The methods used to learn speaking are } \\
\text { less diverse. }\end{array}$ & $\begin{array}{l}\text { With AFORN, lecturers have a variety of methods in teaching } \\
\text { English }\end{array}$ \\
\hline 7 & $\begin{array}{l}\text { Student pronunciation of vocabulary in } \\
\text { English still needs improvement }\end{array}$ & $\begin{array}{l}\text { With AFORN, students' ability in pronunciation of } \\
\text { vocabulary in English is getting better }\end{array}$ \\
\hline 8 & Limited vocabulary mastery & Students have more vocabulary \\
\hline 9 & $\begin{array}{l}\text { Lack of knowledge about expressions } \\
\text { for certain conversation topics }\end{array}$ & $\begin{array}{l}\text { Students know appropriate expressions for conversation with } \\
\text { certain topics }\end{array}$ \\
\hline 10 & $\begin{array}{l}\text { The ability to arrange words into } \\
\text { sentences is still low }\end{array}$ & $\begin{array}{l}\text { Students are able to arrange scrambled words into correct } \\
\text { sentences }\end{array}$ \\
\hline 11 & $\begin{array}{l}\text { The ability to listen to spoken texts is } \\
\text { low (receptive skills) }\end{array}$ & $\begin{array}{l}\text { Students are accustomed to spoken texts that are heard so that } \\
\text { their ability to understand spoken texts increases }\end{array}$ \\
\hline 12 & Confidence to speak in English is low. & $\begin{array}{l}\text { Students are more confident because they often get access } \\
\text { with English material without being limited by space and time }\end{array}$ \\
\hline 13 & Low motivation to learn English & $\begin{array}{l}\text { Students are more active in practicing English because the } \\
\text { media used is attractive and flexible }\end{array}$ \\
\hline
\end{tabular}

The results showed that AFORN has been able to answer all the hypotheses in this study. This application is proven to be able to help students in learning English, especially speaking competence (speaking skills). AFORN is able to facilitate students to practice speaking anywhere, both inside and outside the English language lecture process. This is supported by the various features in Android-based mobile phones as well as their flexible and practical nature. Various features in AFORN that can support students to develop their speaking competence in English can be seen in Table 4.7 below. 
Table 4.5 Data on Features in AFORN that Can Support Speaking Ability

\begin{tabular}{|c|c|c|}
\hline $\begin{array}{l}\text { Input (Features in } \\
\text { AFORN) }\end{array}$ & Aspects of Speaking skills & Output (Student Speaking skills) \\
\hline $\begin{array}{l}\text { Vocabulary (using Text } \\
\text { to Speech and Speech } \\
\text { Recognizer feature) }\end{array}$ & Pronunciation & $\begin{array}{l}\text { - Students can practice pronouncing vocabulary related } \\
\text { to their study program correctly and correctly. With the } \\
\text { Text to Speech feature, students can learn the correct } \\
\text { pronunciation of a word. Then with the Speech } \\
\text { Recognizer feature they can record their voices while } \\
\text { practicing pronouncing the vocabulary. }\end{array}$ \\
\hline $\begin{array}{l}\text { Useful Expresssion } \\
\text { (using Text to Speech } \\
\text { feature) }\end{array}$ & $\begin{array}{l}\text { Pronunciation and } \\
\text { Intonation }\end{array}$ & $\begin{array}{l}\text { - Students can learn various kinds of linguistic } \\
\text { expressions about nursing material and can practice } \\
\text { pronouncing them with the right intonation. }\end{array}$ \\
\hline $\begin{array}{l}\text { Tasks (exercises); } \\
\text { consists of three types } \\
\text { of: Jumbled Words, } \\
\text { Listening Practice, and } \\
\text { Group Assessment }\end{array}$ & Grammar and Vocabulary & $\begin{array}{l}\text { - Through Jumbled Words students can learn correct } \\
\text { English grammar as the basic capital to improve their } \\
\text { speaking skills. } \\
\text { - Through Listening Practice students can practice their } \\
\text { listening skills as input in speaking competence. } \\
\text { - Through Group Assessment, students can practice their } \\
\text { ability to use the vocabulary and linguistic expressions } \\
\text { they have learned before. }\end{array}$ \\
\hline
\end{tabular}

Through the implementation of this mobile learning, students have more opportunities to practice their speaking skills outside of face-to-face lectures. The material presented in this application is also easy to understand because it has focused on topics/themes related to current nursing materials. Brief and concise materials make it easier for students to learn and memorize some vocabulary and linguistic expressions according to the topic being studied.

Learning English using AFORN has indeed been able to improve students' speaking skills, but there are still some obstacles related to the implementation process of this application in learning English. The first obstacle is related to the process of monitoring students. During the face-to-face learning process (in class), lecturers are still able to guide and assist students in applying AFORN.

Lecturers are able to help students if they encounter difficulties in accessing or understanding the content of the material in this application. However, when the students access this application outside of class, the lecturer cannot know for sure how many times or how often students access this application to practice speaking. Therefore, better monitoring is needed regarding the frequency of students accessing this application.

The second obstacle is that this application is not interactive enough to help students practice speaking. The activities presented in AFORN mostly only encourage students to study independently (self-study) or practice independently (self-practice), while students still need facilitators or partners to practices. It can be concluded from the results of student interviews that they still need a facilitator in learning English. Therefore, AFORN cannot be the only main source in learning English, but this application can be a complementary media that can facilitate students in learning English.

\section{CONCLUSION}

After carrying out all the stages of activities in action research, it can be concluded that the use of AFORN as a learning medium (m-learning media) is beneficial to improve English skills, especially speaking skills. AFORN, which in its manufacture adheres to the principles of m-learning, helps students to do selflearning. By using AFORN, students' efforts to improve their abilities can be carried out independently and carried out anywhere and anytime, not necessarily in an English class. The learning model using AFORN is very interesting and easy to use because it can be installed on a smartphone. AFORN is a complementary learning medium besides books, handouts, and materials in the form of Ms. PPT commonly used by lecturers.

AFORN as the complementary learning tool was really helpful for students to learn that they can access it as their own schedule and timeline. AFORN give the students more time to look up other resources. It also promotes autonomy in learning process. Generally, AFORN gives flexibility in learning with the students' phase.

Due to the limited time of the study, this action research was only carried out in 1 cycle. The next research should use two cycles to get more valid results and more accurate data. The use of AFORN becomes a supplement for face to face learning process to help students learn English, but the lecturer can still use other learning media in the teaching and learning process of English. In addition, the implementation of the test needs to be done as a step to monitor the use of AFORN by students.

\section{AUTHOR'S CONTRIBUTION}

The first and second authors contributed to the design and implementation of the research (Planning, Implementation, Observation, and Reflection stages). Both authors also collaborated in the data collection and 
data analysis. Besides, each author gave contribution to the writing of the manuscript, including the content, the layout, and the format of the manuscript.

\section{ACKNOWLEDGMENTS}

This paper was presented in the $67^{\text {th }}$ TEFLIN International Virtual Conference and the $9^{\text {th }}$ ICOELT 2021 on 9-11 September 2021 in Padang, Indonesia. The researchers would like to express their gratitude to Health Polytechnic of Ministry of Health in Yogyakarta in funding this research. In addition, the gratitude also goes to all respondents who have participated in this research and all parties who have contributed to this research so that this paper can be published.

\section{REFERENCES}

[1] J. Richards, Communicative Language Teaching Today, vol. 25, no. 2. 2006.

[2] W. Gadzama, B. Joseph, and T. State, "Global Smartphone Ownership , Internet Usage And Their," no. September, pp. 0-10, 2019.

[3] D. Rochmawati, "AFORN (Active English for Nursing), An M-Learning Model to Enhnce Nursing Students' Speaking Skill," Sanata Dharma University Yogyakarta, 2015.

[4] A. \& C. C. G. Burns, "Teaching Speaking: A Holistic Approach."

[5] A. Burns, "Teaching speaking: Towards a holistic approach Anne Burns Teaching Speaking: Towards A Holistic Approach," no. November 2016, 2017.

[6] J. Eison and D. Ph, "Active Learning - Creating Excitement in the Classroom - Handout.pdf," 2010.

[7] T. M. Miangah and A. Nezarat, "Mobile-Assisted Language Learning," vol. 3, no. 1, pp. 309-319,
2012.

[8] L. C. G. Cabanban, "Development of mobile learning using android platform," Int. J. Inf. Technol. Comput. Sci., vol. 9, no. 1, pp. 98-106, 2013.

[9] A. \& J. T. Kukulska-Hulme, "Mobile Learning," 2019.

[10] T. Elias, "Principles for Mobile Learning," Int. Rev. Res. Open Distance Learn., vol. 12.2, pp. 144-156, 2011.

[11] A. Kukulska-Hulme and L. Shield, "An overview of mobile assisted language learning: From content delivery to supported collaboration and interaction," ReCALL, vol. 20, no. 3, pp. 271-289, 2008, doi: 10.1017/S0958344008000335.

[12] S. Y. Yoon and N.-Y. Kim, "To Flip or Not to Flip: A Comparative Study on Flipped, Blended, and Conventional Learning in EFL Korean Context," $J$. Asia TEFL, vol. 17, no. 2, pp. 463-478, 2020.

[13] A. Burns, "[Anne_Burns]_Collaborative_Action_Research_f or_Eng(BookFi).pdf.”.

[14] B. Basheer Nomass, "The Impact of Using Technology in Teaching English as a Second Language," English Lang. Lit. Stud., vol. 3, no. 1, pp. 111-116, 2013, doi: 10.5539/ells.v3n1p111.

[15] J. W. Creswell, Educational research: Planning, Conducting, and Evaluating Quantitative and Qualitative research, 6th edition. 2012.

[16] M. Sarrab and L. Elgamel, "M Obile L Earning ( ML Earning ) and," Int. J. Distrib. Parallel Syst., vol. 3, no. 4, pp. 31-39, 2013. 